VOLUME XV, NO. 4, 1996

\title{
REVIEWS IN ANALYTICAL CHEMISTRY
}

\section{TABLE OF CONTENTS}

Advances in Membrane Inlet Mass Spectrometry (MIMS)

Frants R. Lauritsen and Tapio Kotiaho

Analysis of Milk Sample: A Voltammetric Approach

Jyotsna Shukla and K.S. Pitre

Nuclear Magnetic Resonance in the Analysis of Dairy Products

Elvino Brosio and Renato Barbieri 273

Copyright 1996

FREUND PUBLISHING HOUSE, LTD.

Suite 500, Chesham House

150 Regent Street

London W1R 5FA

England 